\title{
Book Review: Salem, Feryal. The Emergence of Early Sufi Piety and Sunnī Scholasticism: 'Abdallāh b. al-Mubārak and the Formation of Sunnī Identity in the Second Islamic Century (Brill, 2016). ISBN: 9789004310292,166 pages
}

\section{Souhayla Taiai ${ }^{*}$ ()}

The book titled "The Emergence of Early Sufi Piety and Sunnī Scholasticism: 'Abdallāh b. al-Mubārak and the Formation of Sunnī Identity in the Second Islamic Century" is a monograph in which the author focuses on Abdallāh b. al-Mubārak in order to shed more light on the developments in the Second Islamic Century. The first three hundred years are often considered to be the formation period of the Islamic civilization, not only in terms of political conquests and geographical expansion, but also in terms of socio-economic and intellectual developments. One of the broadest appearing categories is perhaps the Sunn̄̄ Vs Shi'̄i divide, whose main elements started to appear, but neither of which was crystallized as yet. The Shi'̄i identity is beyond the scope of this study since the author explicitly focused on the Sunn̄i identity. More specifically, she focused on three main points, namely zuhd, hadith, and jihad, with the aim of better understanding how they were viewed, formulated, and practiced in the early years of the Islamic civilization. To do this, Salem chose Ibn al-Mubārak as a prominent figure in the three domains. He is prominent in zuhd because his kitāb al-zuhd is the earliest book written on the matter, and it set the trends for the new literature of kutub al-zuhd. The latter became one of the main sources for what came to be the tasawwuf literature. He is prominent in hadith because he was reported to have travelled frequently in order to collect and transmit hadith from the different regions under Muslim control. He was therefore a disciple of some of the main figures of his time, such as Imām Abu Hanīfa and Imām Mālik b. Anas. He is prominent in jihād because he was also a fighter at the Byzantine frontiers.

\footnotetext{
* Corresponding author: Souhayla Taiai (PhD Candidate), Ibn Haldun University, Alliance of Civilizations Institute, Istanbul, Turkey. E-mail: souhayla.taiai@gmail.com ORCID: 0000-0002-0860-3872 
Taking these into account, the author's aim is to "situate him within the larger context of Late Antiquity and examine his interactions with the various perceptions of piety and martial valor prevalent in this period" (p.1). The author's main claim is that "since the muhaddithun of Islam's formative period were the bedrock of the then developing Sunnī identity, a more profound understanding of the vision of piety espoused by these scholars is important because it inevitably influenced later conceptions of what types of devotional practices are considered essential to and within the bounds of Sunnī Islam" (p.3). As for her approach, she described it as being in a mid-way between Fred Donner's descriptive and skeptical approaches to primary sources ${ }^{1}$ by "demonstrat[ing] how the classical sources portray aspects of the life of Ibn al-Mubārak, without either rejecting information that cannot be factually disproven or unequivocally accepting the veracity of all that is reported about this early figure"(p.8).

While this is how the author describes her endeavor, there seem to be as least two main implicit claims in the book that the author challenges. The first one is a claim against the opinion that Islam is a religion of fighting, which has nothing to do with spirituality; and the second one is a claim against the general understanding of $z u h d$ as complete withdrawal or detachment from the world and the suppression of all desires through harsh practices.

The first claim is presented by scholars who explain the presence of tasawwuf as an influence from Eastern Christian forms of asceticism, which were prevailing in the conquered ex-byzantine areas. ${ }^{2}$ Following this claim, the concept of zuhd would be translated as asceticism, as a direct reference to the harsh practices and total isolation similar to Christian monasticism. ${ }^{3}$ As for Zāhid (and later on Sufi), they become linked to some people who have gone beyond the "standard" profile of a Muslim person into demonstrating his higher level of piety through a different

1 Fred Donner put Western scholarship on the early period of Islam into four main categories, namely descriptive, source-critical, tradition-critical, and skeptical. He argues that the difference among the approaches stems from both the availability or scarcity of early Islamşc primary sources as well as the ideological background of different authors. For more details see Fred M. Donner, Narratives of Islamic Origins: the beginnings of Islamic historical writing (Darwin Press, 1998).

2 For discussions on the Christian and Indian influence on Sufism see, among others, Julian Baldick, Mystical Islam - An Introduction to Sufism (I.B Tauris, 2012), 15-24; Ofer Kafri-Livne, "Early Muslim Ascetics and the World of Christian Monasticism" Jerusalem Studies in Arabic and Islam 20 (1996): 105-129; Reynold A. Nicholson, The Mystics of Islam (London: Routledge and K. Paul, 1963); Annemarie Schimmel, Mystical Dimensions of Islam (The University of North Carolina Press, 1975).

3 For more detailed information, see the entry "asceticism" in Encyclopedia Britannica. 
lifestyle. ${ }^{4}$ This assumption stems from the focus of the literature on some key figures ${ }^{5}$ more than others, which led to taking for granted Sufis as a different category from Muslim, and which shifted the debate towards the dichotomy between ascetics and mystics among some famous Sufi figures. The ascetics are described as focusing on self-denial and renunciation. The mystics are described as focusing on Divine love and intimacy. In fact, the history of early Sufism is described as a shift form the early practices of asceticism towards increasing aspects of mysticism. ${ }^{6}$

If Tasawwuf or Zuhd were a continuation of Byzantian monastic practices, then, we would expect to find some sort of monasteries within Muslim lands. Or, at least, we would not find someone who is an ascetic to be involved in the social, economic, political, and military aspects of life. In other words, a figure such as Ibn al-Mubārak, who is praised as one of the founding figures of both the hadith and tasawwuf disciplines, could not be found. Why? Because he was a scholar, a merchant, and a fighter. Moreover, he wrote the first book on zuhd, titled Kitāb al-zuhd. Therefore, we cannot assume that he did not take the spiritual or pious aspect into consideration. As a result, this book provides important evidence to raise a question on the extent to which tasawwuf can be considered a continuation of Christian and Jewish ascetic or, for that matter, Indian mystical practices.

From my understanding, it seems that the author argues that while some tasawwuf practices may share the same features with already existing ascetic practices, the non-contradictory view between piety and worldly involvement was something new and proper to Islam. In this aspect, Ibn al-Mubārak ${ }^{7}$ presents only one example of such a figure, while it was apparently shared among most scholars of his time (the author gave the example of Imām Abu Hanīfa who was a businessman). As a result, the second claim about the definition of $z u h d$ also changes from asceticism to a set of pious rules and principles, which were driven from the Qur'an, Sunnah, Hadith, practices of Sahäba, Tabi'un, and Tabi' '̌ Tabi'un (these form the content of Kitāb

4 Annemarie Schimmel described the change in lifestyle as a conversion to Sufism, as if it were the adoption of a new religion. See Schimmel, Mystical Dimensions of Islam, 35.

5 Ibrahim b. Adham is given as an example for ascetics, Fudayl b. Iyad is given as an example for mystics. See Schimmel, Mystical Dimensions of Islam, 36-37; Christopher Melchert, "The Transition from Asceticism to Mysticism at the Middle of the Ninth Century C.E." Studia Islamica 83 (1996), 54; Leah Kinberg, "What is Meant by Zuhd?" Studia Islamica 61 (1985), 42; Ahmet T. Karamustafa, Sufism: the Formative Period (Edinburg: Edinburg University Press, 2007), 1-2.

6 See Melchert, "The Transition from Asceticism to Mysticism at the Middle of the Ninth Century C.E.”; Alexander Knysh, Islamic Mysticism: A Short History (Leiden: Brill, 2000).

7 Before Feryal Salem, Alexander Knysh mentioned Ibn al-Mubarak in his book titled Islamic Mysticism: a Short History in 2010. 
al-zuhd). In other words, it is simply the Islamic practical ethics, for there was no distinction back then between Sufis and non-Sufis. This goes in line with authors such as Leah Kinberg warned about the risk of using one concept (i.e. asceticism) from a specific context (i.e. Christian ascetic practices) as a direct translation of a concept (i.e. $z u h d$ ) from another context (i.e. Islamic zuhd practices). After studying some major primary sources on the subject, Kinberg came to the conclusions that "zuhd is not something destined for a selected limited group of people, but rather a code of behavior that should be followed by any pious Muslim"; that "the term Muslim becomes equivalent to the term zăhid, and practicing Islam is parallel to practicing Zuhd" ; and that "zuhd, in the pious Islamic milieu, should be understood as a general way of conduct, or simply as ethics."

Overall, I enjoyed reading this book, and I could feel the difficulty in dealing with such a topic. The first difficulty stems from its time scope. The primary sources available to historians of the formative period of Islamic civilization are limited as compared to subsequent times. The second difficulty is in the nature of the topic, which brings about social, intellectual, cultural, political aspects and various view on Islamic history. However, I guess that this last point also makes it more relevant and more enjoyable for a wider range of audiences.

8 Kinberg, "What is Meant by Zuhd?" Studia Islamica 61 (1985): 41.

9 Kinberg, "What is Meant by Zuhd?", 44. 